\title{
Effects of chemical weapons on cancer development in human
}

\author{
Belal A. Muhammad ${ }^{1,2}$ \\ ${ }^{1}$ Biomedical Research Unit, Sulaimani Polytechnic University, Sulaimani, Kurdistan region, Iraq. \\ ${ }^{2}$ Department of Medical Laboratory Science, Komar University of Science and Technology, Sulaimani, \\ Kurdistan region, Iraq.
}

Corresponding Author: belal.muhammad@spu.edu.iq

Received | December 28, 2015

Accepted | January 20, 2016

\begin{abstract}
Although use of chemical weapons has low probability, it can cause a large scale casualties among exposed people if it is used. These kind of weapons have been used by human being since ancient history. However, the first large scale usage started with World War I followed by World War II. Several regulations and guidelines have been set by different organizations such as North Atlantic Treaty Organization and Organization for the Prohibition of Chemical Weapons to limit the usage of these weapons. However, till the present time the world is not free from the risk of these weapons on human life.

While the effects of chemical weapons on certain human systems including respiratory and immune systems as well as the dermatological complications have been extensively studied, the relation between chemical weapons and cancer development has not been fully understood. This review addresses the definition and usage of chemical weapons in addition to the types of chemical agents used in their production. Evidences about the chemical weapons and cancer development have also been thoroughly discussed. In summary, it appears that data regarding carcinogenicity of chemical weapons in human are both limited and contradictory. Accordingly, any claim about the carcinogenic effects of these kind of weapons in the exposed victims need to be properly validated.
\end{abstract}

Key words: Chemical weapons, Chemical agents, Cancer, Sulfur Mustard, Nerve agents.

\section{Introduction}

Since ancient age, different forms of chemical weapons have been used by human being. The greatest advance in using and developing these weapons has occurred during the $19^{\text {th }}$ century especially with the start of World War I (WWI) (Szinicz, 2005). The effects of chemical weapons on certain human systems such as respiratory and immune systems as well as the dermatological complications have been extensively studied in the literature (Case and Lea, 1955, Beebe, 1960, Dacre and Goldman, 1996, Ghanei and Vosoghi, 2002, Salih et al., 2008, Salih et al., 2009, Ghanei and Harandi, 2010, Haines and Fox, 2014, Gupta, 2015). However, the association between chemical weapons and cancer development remained poorly understood.

The concern of cancer development related to chemical weapon probably paved from the fact that some of the chemical agents used in 
manufacturing the chemical weapons such as mustard or sulfur mustard (SM) gases are classified as group 1 carcinogens to human by the International Agency for Research on Cancer (IARC) (IARC, 2012). However, how cancer of a specific organ or site is developed after exposure to these chemicals is an important issue yet to be clarified. Available data in the literature are sparse, not consistence, and have lots of limitations. This review is an effort toward clarification of the concept of chemical weapons and their relationship to cancer development in human.

\section{Definition of chemical weapons}

Chemical weapons have been described in different ways. To simplify this, specialists considered any weapon that uses a manufactured chemical agent to harm humans as a chemical weapon. However, to be more accurate, the term chemical weapon and chemical agents has been carefully defined by some organizations such as Organization for the Prohibition of Chemical Weapons (OPCW) and North Atlantic Treaty Organization (NATO). OPCW has issued an important document in nineties known as Chemical Weapons Convention (CWC) and asked the countries across the world to support it. Up to now, more than 190 countries have participated in this Convention which contains enormous information about the chemical weapons. The Convention aims to eliminate an entire category of weapons of mass destruction by prohibiting the development, production, acquisition, stockpiling, retention, transfer or use of chemical weapons by States Parties (OPCW, 2015).
According to the OPCW, the term chemical weapon can be applied to any toxic chemical or its precursor that can cause death, injury, temporary incapacitation or sensory irritation through its chemical action. The same reference stated that munitions or other delivery devices designed to deliver chemical weapons, whether filled or unfilled, may also be considered as weapons themselves (OPCW, 2015). Chemical agents are exist either naturally or developed through different industries. The above definition can be applied to both of these categories to include any chemical agent used in the production of weapons of mass destruction. Similarly, a chemical agent has been defined by NATO as a chemical substance which is intended for use in military operations to kill, seriously injure or incapacitate people because of its physiological effects (NATO Handbook on the Medical Aspects, 1996). By looking at both of the definitions above it appear that the purpose of use is more important than the chemical agent itself.

Some toxic chemical agents are necessary for human use in agriculture and industries such as riot control agents, herbicides, smoke and flame. Therefore, these chemicals have been excluded from the definition of chemical weapon. However, use of these chemicals in large quantities may cause a mass destruction. Moreover, some of the chemical agents may be used together as a mixture, and also, new agents are constantly being discovered. A proper solution for this would be to expand the definition of chemical weapon to include any chemical substances that its intended purpose is prohibited by the CWC (OPCW, 2015). 


\section{Historical background of the usage of chemical weapons}

The usage record of chemical agents as weapons in war can be traced back centuries down to prehistoric times. Some simple form of chemicals such as toxic fumes has been used in wars since the fifth century B.C. (WMD, 2015). However, their usage was limited due to restricted knowledge at that time. At early years of $19^{\text {th }}$ century the knowledge about chemistry and the hazardous effect of chemical agents has increased and resulted in the usage of some chemicals in the production of mass destruction weapons. The first effective use of chemical warfare emerged in the World War I (WWI) starting with Germans attack with chlorine gas against their enemies at Ypres, Belgium which resulted in massive casualties (Szinicz, 2005, Chemical Weapons, 2015, WMD, 2015). Since then, the usage of chemical weapons have been expanded and more dangerous chemical agents have been used in their production. One of the most series usage in the modern age was that practiced by the Iraqi forces ruled by Saddam Hussain's regime which resulted in thousands of casualties (Szinicz, 2005, Chemical Weapons, 2015, WMD, 2015).

Table 1 shows selected historical usage of different types of chemical weapons within the modern age (from 1914).

\section{Types of chemical agents used in chemical weapons}

Many types of chemical agents have been used in manufacturing of chemical weapons. These agents are classified into several groups based on their biological mode of action on human body.

Table 2 shows some characteristics of main groups of chemical agents including choking, blister, blood, nerve and riot control agents.

\section{Chemical weapons and cancer}

Cancer is a multifactorial disease which may develop over time as a result of exposure to many chemical, biological, or radiological agents. Among the different types of chemical agents used to make mass destructive chemical weapons, sulfur mustard (SM) has been reported to be carcinogenic (IARC, 1975, IARC, 1987), especially in case of long (occupational) exposure (Ghanei and Vosoghi, 2002). However, carcinogenicity of SM following a single exposure is a subject of controversy.

It has been long shown that chronic exposure (i.e., long time continuous exposure) to SM increased the risk of respiratory cancer (Wada and Kambe, 1968, Manning et al., 1981). Studies have also shown the mortality rate of those who have injured from SM during WW I among the British and American These findings were further supported by a later study performed by Easton et al, (1988) who showed evidence about lung and upper respiratory tract cancers following mustard gas exposure (Easton et al., 1988).

Development of other types of cancer such as chronic myelocytic leukemia (CML) in war victims exposed to mustard gas was also shown to be increased (Ghanei and Vosoghi, 2002). In a more recent study, an Iranian team have performed a big long-term follow-up cohort study 
Table 1: Historical usage of chemical weapons. Selected usage of different types of chemical weapons within the modern age (from 1914) is presented. Adapted from (Szinicz, 2005, OPCW Fact Sheet 4, 2015, WMD, 2015). A full chronological usage list of chemical weapons across the history is presented in the supplementary Table SI.

\begin{tabular}{|c|c|}
\hline Time & Description \\
\hline \multirow{11}{*}{ 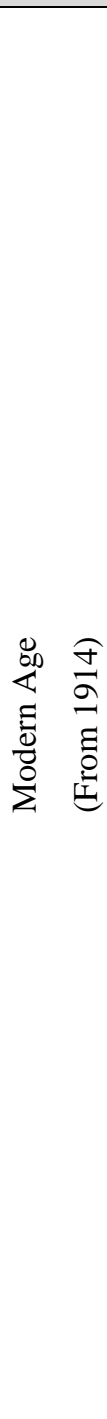 } & $\begin{array}{l}\text { November 1914-First use of the irritant chloroacetone by French Forces and soon after by } \\
\text { Germany and Russia (Szinicz, 2005) }\end{array}$ \\
\hline & $\begin{array}{l}\text { April 22, 1915-Germans attack the French with a lung-damaging agent chlorine gas at Ypres, } \\
\text { France. This was the first significant use of chemical warfare in WWI as weapon of mass } \\
\text { destruction (Szinicz, 2005, Chemical Weapons, 2015, WMD, 2015) }\end{array}$ \\
\hline & $\begin{array}{l}\text { September 25, 1915-First British chemical weapons attack; chlorine gas is used against Germans } \\
\text { at the Battle of Loos (Szinicz, 2005, Chemical Weapons, 2015, WMD, 2015) }\end{array}$ \\
\hline & $\begin{array}{l}\text { December, 1915-First use of the lung-damaging agent phosgene by German Forces (Szinicz, } \\
\text { 2005) }\end{array}$ \\
\hline & June 1918-First U.S. use of gas in warfare (Chemical Weapons, 2015, WMD, 2015) \\
\hline & $\begin{array}{l}\text { 1919-British use Adamsite against the Bolsheviks during the Russian Civil War (Chemical } \\
\text { Weapons, 2015, WMD, 2015) }\end{array}$ \\
\hline & $\begin{array}{l}\text { 1922-1927-The Spanish use chemical weapons against the Rif rebels in Spanish Morocco } \\
\text { (Chemical Weapons, 2015, WMD, 2015) }\end{array}$ \\
\hline & $\begin{array}{l}\text { 1935-1936-Use of tear and mustard gases against Ethiopians during Italian invasion of Abyssinia } \\
\text { (Szinicz, 2005, Chemical Weapons, 2015, WMD, 2015) }\end{array}$ \\
\hline & $\begin{array}{l}\text { 1963-1967-Use of chemical weapons (phosgene and mustard gases) by Egypt against Yemen } \\
\text { (Szinicz, 2005, Chemical Weapons, 2015, WMD, 2015) }\end{array}$ \\
\hline & $\begin{array}{l}\text { 1983-1988-Use of sulphur mustard, tabun and sarin by Iraqi Forces during Iraq-Iran war (Szinicz, } \\
\text { 2005, Chemical Weapons, 2015, WMD, 2015) }\end{array}$ \\
\hline & $\begin{array}{l}\text { 1987-1988-Use of different kind of chemical weapons (hydrogen cyanide, mustard gas, and sarin) } \\
\text { by Iraqi forces against the Kurds, most notably in the in the Anfal Campaign and Halabja Massacre } \\
\text { in } 1988 \text { (Szinicz, 2005, Chemical Weapons, 2015, WMD, 2015) }\end{array}$ \\
\hline
\end{tabular}

for Iranian veterans who exposed to SM versus unexposed individuals and concluded that the single exposure to the SM during the Iraq-Iran war increased the incidence of cancer (Zafarghandi et al., 2013). However, soon after, this claim has been heavily disapproved by some other Iranian researchers criticizing inaccuracy in the parameters taken into account (Karbasi-Afshar et al., 2013).

SM has been shown to be mutagenic causing mutations and chromosomal aberrations in a variety of different species using many different laboratory techniques (Auerbach, 1947, Heston, 1950, Dacre and Goldman, 1996). 
Table 2: Types and characteristics of chemical agents based on their mode of action (i.e. the route of penetration and their effect on the human body) adapted from (OPCW Fact Sheet 4, 2015).

\begin{tabular}{|c|c|c|c|c|c|}
\hline Agent & Persistency & $\begin{array}{l}\text { Rate of } \\
\text { action }\end{array}$ & $\begin{array}{l}\text { Mode of } \\
\text { action }\end{array}$ & Physiological effects & Dispersal \\
\hline \multicolumn{6}{|l|}{ Choking Agents } \\
\hline Chlorine $(\mathrm{Cl})$ & Low & Variable & Absorption & Fluid builds up in lungs, & \\
\hline Phosgene (CG) & Low & Delayed & through lungs & choking victim & Gas \\
\hline Diphosgene (DP) & Low & Delayed & & & \\
\hline Chloropicrin (PS) & Low & Rapid & & & \\
\hline Blister Agents & & & & Burns skin, mucous & \\
\hline Sulfur mustard (H, HD) & Very high & Delayed & Absorption & membranes and eyes; causes & Liquid, \\
\hline Nitrogen mustard (HN) & High & Delayed & through lungs, & large blisters on exposed & aerosol, \\
\hline Phosgene oxime (CX) & Low & Immediate & skin & skin; blisters windpipe and & vapor and \\
\hline Lewisite (L) & High & Rapid & & $\begin{array}{l}\text { lungs; large number of } \\
\text { casual- ties, low percentage } \\
\text { of deaths }\end{array}$ & dust \\
\hline $\begin{array}{l}\text { Blood Agents } \\
\text { Hydrogen cyanide (AC) } \\
\text { Cyanogen chloride (CK) } \\
\text { Arsine (SA) }\end{array}$ & $\begin{array}{l}\text { Low } \\
\text { Low } \\
\text { Low }\end{array}$ & $\begin{array}{c}\text { Rapid } \\
\text { Rapid } \\
\text { Delayed }\end{array}$ & $\begin{array}{l}\text { Absorption } \\
\text { through lungs }\end{array}$ & $\begin{array}{l}\text { Cyanide destroys ability of } \\
\text { blood tissues to utilize } \\
\text { oxygen, causing them to } \\
\text { 'starve' and strangling the } \\
\text { heart }\end{array}$ & Gas \\
\hline Nerve Agents & & & Absorption & Causes seizures, loss of body & \\
\hline Tabun (GA) & Low & Very rapid & through lungs & control; paralyses muscles, & Liquid, \\
\hline Sarin (GB) & Low & Very rapid & (G-Series); & including heart and & aerosol, \\
\hline Soman (GD) & Moderate & Very rapid & contact with & diaphragm; lethal doses can & vapor and \\
\hline Cyclosarin (GF) & Moderate & Very rapid & $\operatorname{skin}(\mathrm{VX})$ & cause death in five minutes & dust \\
\hline VX & Very high & Rapid & & & \\
\hline $\begin{array}{l}\text { Riot Control Agents } \\
\text { Tear Gas (CS) } \\
\text { Pepper Spray (OC) }\end{array}$ & $\begin{array}{l}\text { Low } \\
\text { Low }\end{array}$ & $\begin{array}{l}\text { Immediate } \\
\text { Immediate }\end{array}$ & $\begin{array}{l}\text { Absorption } \\
\text { through lungs, } \\
\text { skin, eyes }\end{array}$ & $\begin{array}{l}\text { Causes tears, coughing and } \\
\text { irritation to eyes, nose, } \\
\text { mouth and skin; constricts } \\
\text { airway and shuts eyes (OC) }\end{array}$ & $\begin{array}{l}\text { Liquid, } \\
\text { aerosol }\end{array}$ \\
\hline
\end{tabular}

However, attempts to seek confirmatory results in laboratory animals have not been consistent (Dacre and Goldman, 1996). Moreover, evidence considering a short-term, high dose single exposure of SM as a direct causative agent of lung cancer is lacking in the literature probably due to its lethality (Gupta, 2015). However, cases of human lung cancer due to long-term exposure to SM are well documented (Ghanei and Harandi, 2010). Therefore, any claim about carcinogenic effect of SM in exposed victims needs strong evidence coupled with careful assessment of parameters taken into account. Till the time of this review preparation, no studies were found in the 
literature to proof the direct carcinogenicity of SM or other chemical agents (such as nerve gases) used in mass destruction weapons especially after a short time single exposure.

Cancer development is a long process which may take several months to several years to appear. This require victims of the chemical weapon to survive long enough to be monitored for any sign of cancer development. However, people who expose to nerve gases die soon after exposure due to the fact that nerve gases are among the most dangerous known chemical agents that could rapidly kill the victims by any route of exposure (Reutter, 1999). This might be the reason why studies about cancer development in people who exposed to nerve agent containing chemical weapons is rare, if any. In contrast, many studies about the effects of SM on human health are available as discussed above.

Other health effects of chemical weapons in human including gene abnormalities have also been studied in the literature. For example, a rare hemoglobin variant known as $\mathrm{Hb}$ Iraq-Halabja has been first reported in a patient from Halabja (Deutsch et al., 1999), a Kurdish city at northern Iraq which was exposed to chemical weapon attack in 1988 by Saddam Hussein's regime. Similarly, mutations in p53 tumor suppressor gene have been detected in Japanese mustard gas workers (Takeshima et al., 1994). However, these mutations have not been firmly linked to carcinogenesis. Moreover, data regarding the effects of SM exposure on human productivity including pregnancy are either lacking or contradictory (Gupta, 2015).
Studies also evaluated the effect of chemical warfare agents on the overall health status of survivors in Halabja including respiratory and dermatological problems as well as immunological defects (Salih, Al-Jaff et al., 2008, Salih, Al-Jaff et al., 2009). In addition, many other health complications following exposure to chemical weapons have also been extensively studied. Since addressing these issues is not within the scope of this review, readers can get a comprehensive view from an excellent book recently published in 2015 entitled "handbook of toxicology of chemical warfare agents" (Gupta, 2015).

\section{Conclusions}

There is no doubt that chemical weapons are among the most dangerous mass destruction weapons ever used in the history. Since it is first large scale usage in WWI millions of casualties have been recorded in different parts of our planet. These casualties can generally be categorized into two main groups based on the outcome of the exposure: (a) victims who exposed to a very high dose of the chemical agents are usually die soon after exposure, (b) those who exposed to less effective dose of the chemical agents show various direct and indirect complications including respiratory, dermatological, and immunological complications.

To a less extent some of these chemical agents such as SM may cause systemic toxicities including immunohematopoietic complications which may lead to carcinogenesis especially in case of prolonged and/or repetitive exposure. However, cut edge evidence regarding tumourigenecity of chemical weapons in human is 
still very limited. Similarly, effects of these agents on productivity, birth defects, and new generation of children derived from survivors are left unclarified. Therefore, it is very important that scientists address these issues and make it clear whether there is any actual risk of genetic abnormalities and malignancies in people who exposed to chemical weapons especially issues related to the productivity and their offspring. Practical studies in this regard will not only provide a better insight into the possible health consequences of these agents but will also reassure the victims and help them to understand the amount of risk they should expect in their remaining life.

\section{References}

Auerbach, C. (1947). The induction by mustard gas of chromosomal instabilities in Drosophila melanogaster. Proc R Soc Edinb Biol. 62, 307-320.

Beebe, G. W. (1960). Lung cancer in World War I veterans: possible relation to mustard-gas injury and 1918 influenza epidemic. J Natl Cancer Inst. $25,1231-1252$.

Case, R. A. and A. J. Lea (1955). Mustard gas poisoning, chronic bronchitis, and lung cancer; an investigation into the possibility that poisoning by mustard gas in the 1914-18 war might be a factor in the production of neoplasia. Br J Prev Soc Med. 9, $62-72$

Chemical Weapons. (2015). Chemical weapons. Fact sheets, critical issues Retrieved December 28th, 2015, Available from:

http://www.reachingcriticalwill.org/resources/factsheets/critical-issues/4582-chemical-weapons.

Dacre, J. C. and M. Goldman (1996). Toxicology and pharmacology of the chemical warfare agent sulfur mustard. Pharmacol Rev. 48, 289-326.

Deutsch, S., R. Darbellay, R. Offord, A. Frutiger, J. Kister, H. Wajcman and P. Beris (1999). Hb IraqHalabja beta10 (A7) Ala-->Val (GCC-->GTC): a new beta-chain silent variant in a family with multiple Hb disorders. Am J Hematol. 61, 187-193.

Easton, D. F., J. Peto and R. Doll (1988). Cancers of the respiratory tract in mustard gas workers. $\mathrm{Br} \mathrm{J}$ Ind Med. 45, 652-659.
Ghanei, M. and A. A. Harandi (2010). Lung carcinogenicity of sulfur mustard. Clin Lung Cancer. 11, 13-17.

Ghanei, M. and A. A. Vosoghi (2002). An epidemiologic study to screen for chronic myelocytic leukemia in war victims exposed to mustard gas. Environ Health Perspect. 110, 519521.

Gupta, R. C. (2015). Handbook of toxicology of chemical warfare agents. London, England, Elsevier: AP: 1 online resource (1,199 pages).

Haines, D. D. and S. C. Fox (2014). Acute and LongTerm Impact of Chemical Weapons: Lessons from the Iran-Iraq War. Forensic Sci Rev. 26, 97-114.

Heston, W. E. (1950). Carcinogenic action of the mustards. J Natl Cancer Inst. 11, 415-423.

IARC (1975). IARC monographs on the evaluation of the carcinogenic risk of chemicals to man: some aziridines, N-, S- \& O-mustards and selenium. IARC Monogr Eval Carcinog Risk Chem Man. 9: $1-268$.

IARC (1987). Overall evaluations of carcinogenicity: an updating of IARC Monographs volumes 1 to 42 . IARC Monogr Eval Carcinog Risks Hum Suppl. 7: 1-440.

IARC (2012). IARC Monographs on the Evaluation of Carcinogenic Risks to Humans, Vol 100, A Review of Human Carcinogens. . IARC Monogr Eval Carcinog Risks Hum. 100.

Karbasi-Afshar, R., Y. Panahi and A. Saburi (2013). Other considerations about carcinogenicity of sulfur mustard. Cancer Causes Control. 24, 2251-2252.

Manning, K. P., D. C. Skegg, P. M. Stell and R. Doll (1981). Cancer of the larynx and other occupational hazards of mustard gas workers. Clin Otolaryngol Allied Sci. 6, 165-170.

NATO Handbook on the Medical Aspects (1996). NATO Handbook on the Medical Aspects of NBC Defensive Operations, "Part III - Chemical":, U.S. Department of Defense, Department of the Army, February 1996.

OPCW (2015). Brief Description of Chemical Weapons, Organization for the Prohibition of Chemical Weapons. Retrieved December 28th, 2015.

OPCW Fact Sheet 4. (2015). What is a Chemical Weapon? Organization for the Prohibition of Chemical Weapons. Retrieved December 28th, 2015, Available from:

https://www.opcw.org/fileadmin/OPCW/Fact_Sheets/ Fact_Sheet_4_-_CW_types.pdf. 
Reutter, S. (1999). Hazards of chemical weapons release during war: new perspectives. Environ Health Perspect. 107, 985-990.

Salih, A. H., B. M. A. Al-Jaff and B. M. M. (2008). The effect of chemical warfare agents on the immune system of survivors in Halabja. Journal of Zankoy Sulaimani (JZS) 11, 41-52.

Salih, A. H., B. M. A. Al-Jaff and B. M. M. (2009). Common health complains among chemical bombardment survivors in halabja. J. Duhok Univ. 12, 312-316.

Szinicz, L. (2005). History of chemical and biological warfare agents. Toxicology. 214, 167-181.

Takeshima, Y., K. Inai, W. P. Bennett, R. A. Metcalf, J. A. Welsh, S. Yonehara, Y. Hayashi, M. Fujihara, M. Yamakido, M. Akiyama and et al. (1994). p53 mutations in lung cancers from Japanese mustard gas workers. Carcinogenesis. 15, 2075-2079.

Wada, S. and S. Kambe (1968). [Air pollution and lung cancer]. Gan No Rinsho. 14, 916-921.

WMD. (2015). Proliferation of Weapons of Mass Destruction (WMD): History of usage and proliferation, Social issues and debate topics webpage, Library Index. Retrieved December 28th, 2015, Available from:

http://www.libraryindex.com/pages/1888/Proliferation -Weapons-Mass-Destruction-WMD-HISTORYUSAGE-PROLIFERATION.html.

Zafarghandi, M. R., M. R. Soroush, M. Mahmoodi, K. H. Naieni, A. Ardalan, A. Dolatyari, F. Falahati, M. Mirmohammadkhani, B. Mousavi and M. Ghanei (2013). Incidence of cancer in Iranian sulfur mustard exposed veterans: a long-term follow-up cohort study. Cancer Causes Control. 24, 99-105. 
Supplementary Table SI: A comprehensive chronological usage of different types of chemical weapons across the history. Adapted from (Szinicz, 2005, Chemical Weapons, 2015, WMD, 2015).

\begin{tabular}{|c|c|}
\hline Date & Description \\
\hline \multirow{3}{*}{ 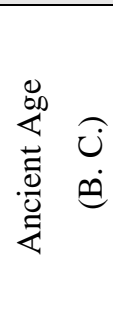 } & $\begin{array}{l}600 \text { B. C., Solon (the Athenian dictator) used Helleborus roots (active ingredients: protoanemonin, steroidal saponines, bufadienolides) to contaminate water } \\
\text { supplies during the siege of Kirrha (Szinicz, 2005). }\end{array}$ \\
\hline & 431-404 B. C., Spartans ignite pitch and sulphur to create toxic fumes at Platea and Delium during the Peloponnesian War (Szinicz, 2005, WMD, 2015). \\
\hline & $\begin{array}{l}\text { About } 200 \text { B. C., Carthaginians used mandrake roots (active ingredients: tropane alkaloids, e.g. scopolamine, atropine) to spoil wine for sedating their } \\
\text { enemies (Szinicz, 2005). }\end{array}$ \\
\hline & 960-1279 A.D., Arsenical smoke used in battle during China's Sung Dynasty (Szinicz, 2005, WMD, 2015). \\
\hline & 1452-1519 A.D., Leonardo daVinci proposes the use of smoke containing arsenic to lay siege to adversary fortifications (Szinicz, 2005). \\
\hline & $\begin{array}{l}\text { Circa } 1570 \text { A.D., The Austrian Knight Veit Wulff von Senftenberg reports on Hunyadi using arsenical smoke when defending Belgrade against the Turks } \\
\text { (Szinicz, 2005). }\end{array}$ \\
\hline & $\begin{array}{l}\text { June 19, } 1845 \text { A.D., } 1095 \text { out of } 1150 \text { men of the Kabyl Tribe Ouled-Rhia died of suffocation in the cave of Nemchia after the French Colonel Pelissier had } \\
\text { given the order to generate smoke by burning freshly cut wood (Szinicz, 2005). }\end{array}$ \\
\hline \multirow{6}{*}{ 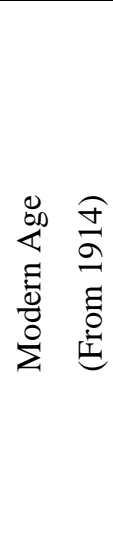 } & August 1914 - First use of the irritant ethylbromoacetate by French military Forces (Szinicz, 2005) \\
\hline & October 1914-First (and only) use of the sneezing agent $o$-dianisidine chlorosulphonate (Niespulver) by German Forces (Szinicz, 2005) \\
\hline & November 1914-First use of the irritant chloroacetone by French Forces and soon after by Germany and Russia (Szinicz, 2005) \\
\hline & $\begin{array}{l}\text { April 22, 1915-Germans attack the French with a lung-damaging agent chlorine gas at Ypres, France. This was the first significant use of chemical warfare } \\
\text { in WWI as weapon of mass destruction (Szinicz, 2005, Chemical Weapons, 2015, WMD, 2015). }\end{array}$ \\
\hline & $\begin{array}{l}\text { September 25, 1915-First British chemical weapons attack; chlorine gas is used against Germans at the Battle of Loos (Szinicz, 2005, Chemical Weapons, } \\
\text { 2015, WMD, 2015). }\end{array}$ \\
\hline & December, 1915-First use of the lung-damaging agent phosgene by German Forces (Szinicz, 2005) \\
\hline
\end{tabular}




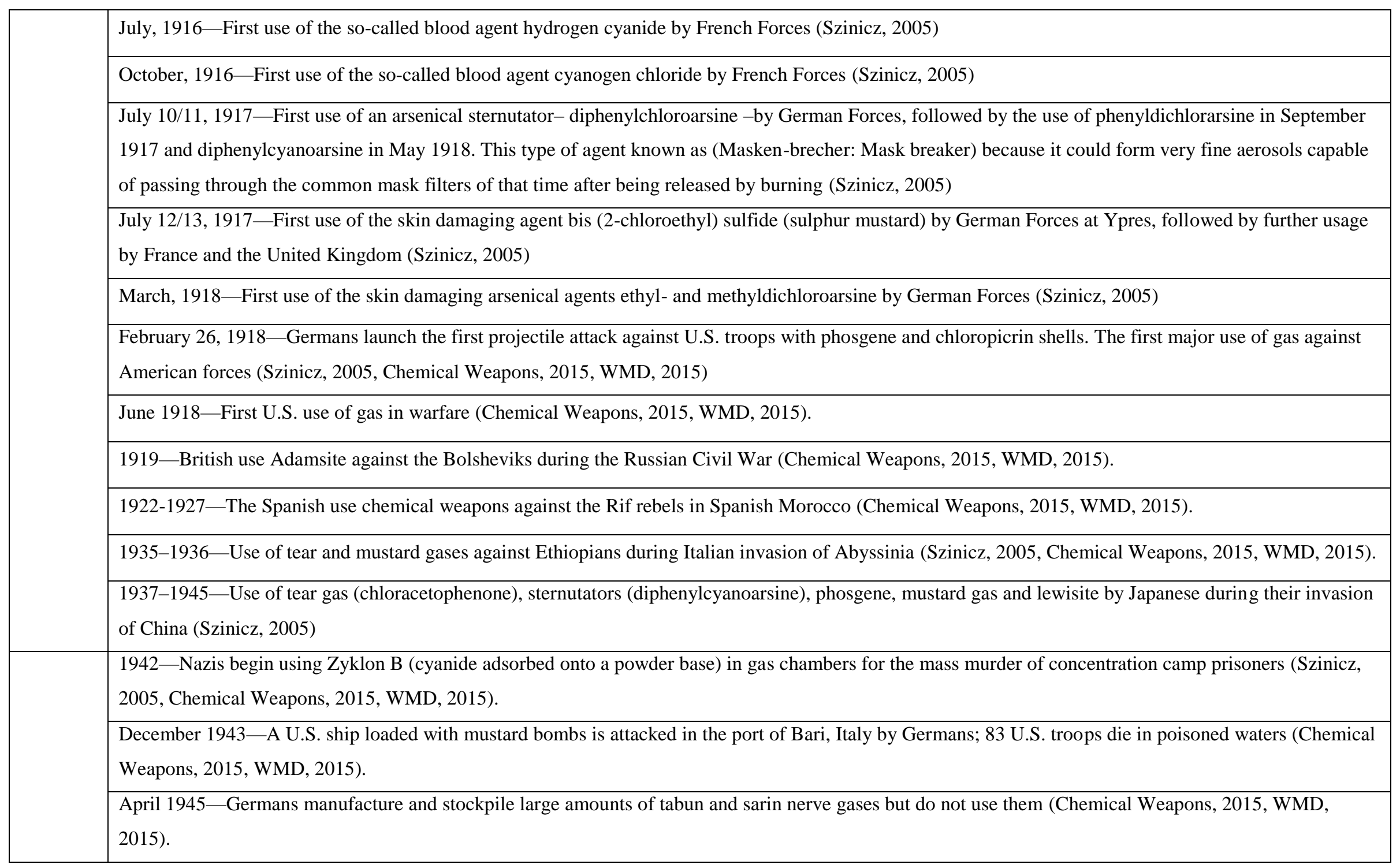


1962-1970-U.S. uses tear gas and four types of defoliant, including Agent Orange, in Vietnam (Szinicz, 2005, Chemical Weapons, 2015, WMD, 2015)

1963-1967-Use of chemical weapons (phosgene and mustard gases) by Egypt against Yemen (Szinicz, 2005, Chemical Weapons, 2015, WMD, 2015). 1975-1983-Alleged use of Yellow Rain (trichothecene mycotoxins) by Soviet-backed forces in Laos and Kampuchea. There is evidence to suggest use of T-2 toxin, but an alternative hypothesis suggests that the yellow spots labeled Yellow Rain were caused by swarms of defecating bees (Chemical Weapons, 2015, WMD, 2015).

1983-1988-Use of sulphur mustard, tabun and sarin by Iraqi Forces during Iraq-Iran war (Szinicz, 2005, Chemical Weapons, 2015, WMD, 2015).

1987-1988 - Use of different kind of chemical weapons (hydrogen cyanide, mustard gas, and sarin) by Iraqi forces against the Kurds, most notably in the in the Anfal Campaign and Halabja Massacre in 1988 (Szinicz, 2005, Chemical Weapons, 2015, WMD, 2015).

1994 and 1995-Aum Shinrikyo terrorist attack in Matsumoto: use of sarin (Szinicz, 2005).

October 23, 2002-Use of fentanyl analogues against rebels: assault made by Russian Special Forces in order to free hostages kept in a music-theatre in

Moscow (Szinicz, 2005). 